\title{
Trends in Selecting Undergraduate Business Majors \& International Enrollment \& Expected Salaries
}

\author{
Ceyhun Ozgur ${ }^{1}$, Yang $\operatorname{Li}^{1} \&$ Grace Rogers ${ }^{1}$ \\ ${ }^{1}$ College of Business, Valparaiso University, Indiana, USA 46383 \\ Correspondence: Ceyhun Ozgur, Valparaiso University, 1909 Chapel Drive Valparaiso, IN 46383, USA. Tel: \\ 219-4-64-5178. E-mail: Ceyhun.ozgur@valpo.edu
}

Received: June 16, 2015

Accepted: June 24, $2015 \quad$ Online Published: August 11, 2015

doi:10.5539/jel.v4n3p45

URL: http://dx.doi.org/10.5539/jel.v4n3p45

\begin{abstract}
The paper begins with a brief review of the literature and how business students choose their major in the U.S. and we list the most popular majors in the U.S. Universities. We also talk about the factors that influenced student's choice. In our next research project, we will not only use a larger sample size but also the sample will come from a few universities to reduce the sampling bias. In this paper, we also talk about changing trends in international students. We talk about the large group of Chinese, Indian, and Arabic students, and we show that with literature and graphical support. In the next section, we analyze one of the up and coming new business majors "Business Analytics" We finish the paper with a discussion of growth of international students both at graduate and undergraduate level, and how we will address the shortcomings of this paper with our next project.
\end{abstract}

Keywords: list of most popular business majors, trends in international student enrollment starting \& mid-career business salaries for each major, list of functions for each major, business analytics major

\section{Introduction}

Two of the authors of this paper conducted a recent survey in which business school students indicated both their choice of academic major and the reasons for this choice. Given the overall focus on this paper on the differences made in popularity of specific majors brought to a school with the influx of large numbers of international students, the reasons students make these choices are very important.

Valparaiso University is a regionally accredited university located in central Indiana. Overall enrollment is approximately 4,000 students. Before examining the results of this survey it is important to note that the array of academic majors varies from one university to another. The most popular majors in the United States schools of business are the following majors:

1). Accounting

2). Finance

3). Business Analytics

4). Operations Management

5). Entrepreneurship

6). Management Information Systems

7). International Business

8). Management

9). Marketing

Appendix 1 at the end of this paper displays related job titles and business functions pertaining to the several majors. Appendix 2 at the end of this paper displays the administered survey that focuses both on the student's choice of major and the reasons for this choice.

Business analytics (BA) refers to the skills, technologies, applications and practices for continuous iterative exploration and investigation of past business performance to gain insight and drive business planning (Wikipedia, 2013). Business analytics focuses on developing new insights and understanding of business 
performance based on data and statistical methods. In contrast, business intelligence traditionally focuses on using a consistent set of metrics to both measure past performance and guide business planning, which is also based on data and statistical methods.

Silver, blogger, utilized a tremendous database of polling data, both historic and current, to accurately predict the winner of all 50 states on the night of the election. He also gave Obama a $91 \%$ chance of winning, going against the media tide calling for a very close race (or a Romney win). And it wasn't a fluke. In 2008, Silver correctly predicted the winner of 49 out of 50 states. For the general public, there was no way to know that the idea for the Parker contest had come from a data-mining discovery about some supporters: affection for contests, small dinners and celebrity. But from the beginning, campaign manager Jim Messina had promised a totally different, metric-driven kind of campaign in which politics was the goal but political instincts might not be the means. He hired an analytics department five times as large as that of the 2008 operation, with an official "chief scientist" for the Chicago headquarters named Rayid Ghani, crunched huge data sets to, among other things, maximize the efficiency of supermarket sales promotions(Wixom et al., 2011).

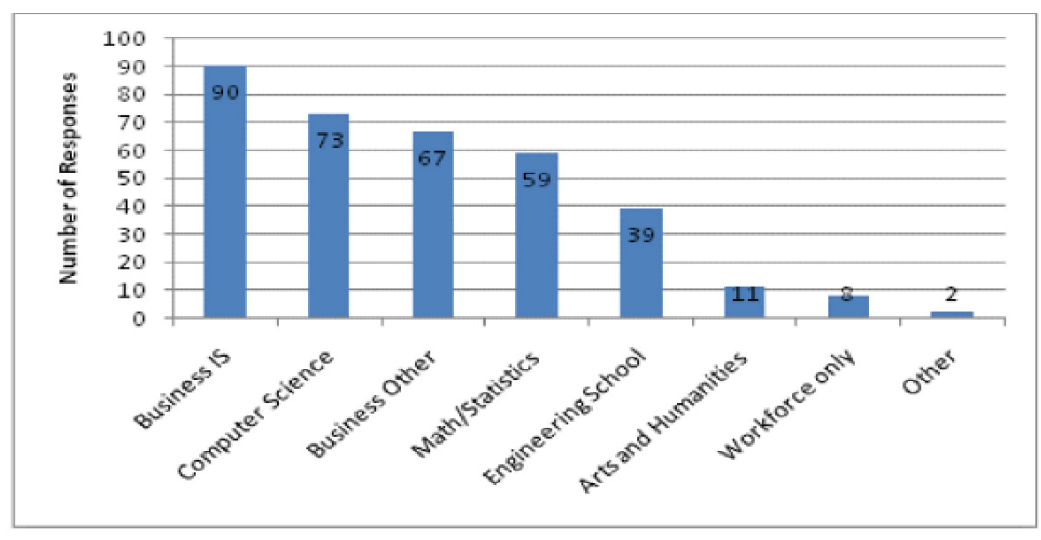

Figure 1. From where do you hire B|skills

Source: B|Congress $\mid$ |survey, based on 219 recruiter responses

This paper uses of different software involving different data.The most popular software is EXCEL, mainly because it's easy availability and low/no cost. However, it suffers from having inadequate menu and not being able to perform certain statistical tests. Instead of EXCEL, instructors prefer SAS, SPSS or MINITAB, mainly because we can do many more statistical tests using these software programs given above. SAS and SPSS can handle large data sets, but the disadvantage of SAS and SPSS is that there is a longer learning curve compared to MINITAB or EXCEL. Another advantage of SAS and SPSS, they can handle problems with large data sets. Utilizing problems with large data sets is very desirable by firms in different industries and what the recruiters are looking for in hiring college graduates in their Business Analytics departments.

In terms of expenditures, even though SAS and SPSS appear a lot more expensive on the surface, schools can save money by using either SPSS or SAS, if they utilize the resources offered to them by SPSS or SAS. Note that software is most desirable, because it is free, however it cannot handle problems with very large data sets. However, this should not be a problem in academic/university setting. However, when students get their first job in Business Analytics/Business Intelligence, they will be required to use a software program like SPSS or SAS. We think they will be better off to be introduced to SPSS or SAS earlier in their career, due to the fairly long learning curve for both software programs. 


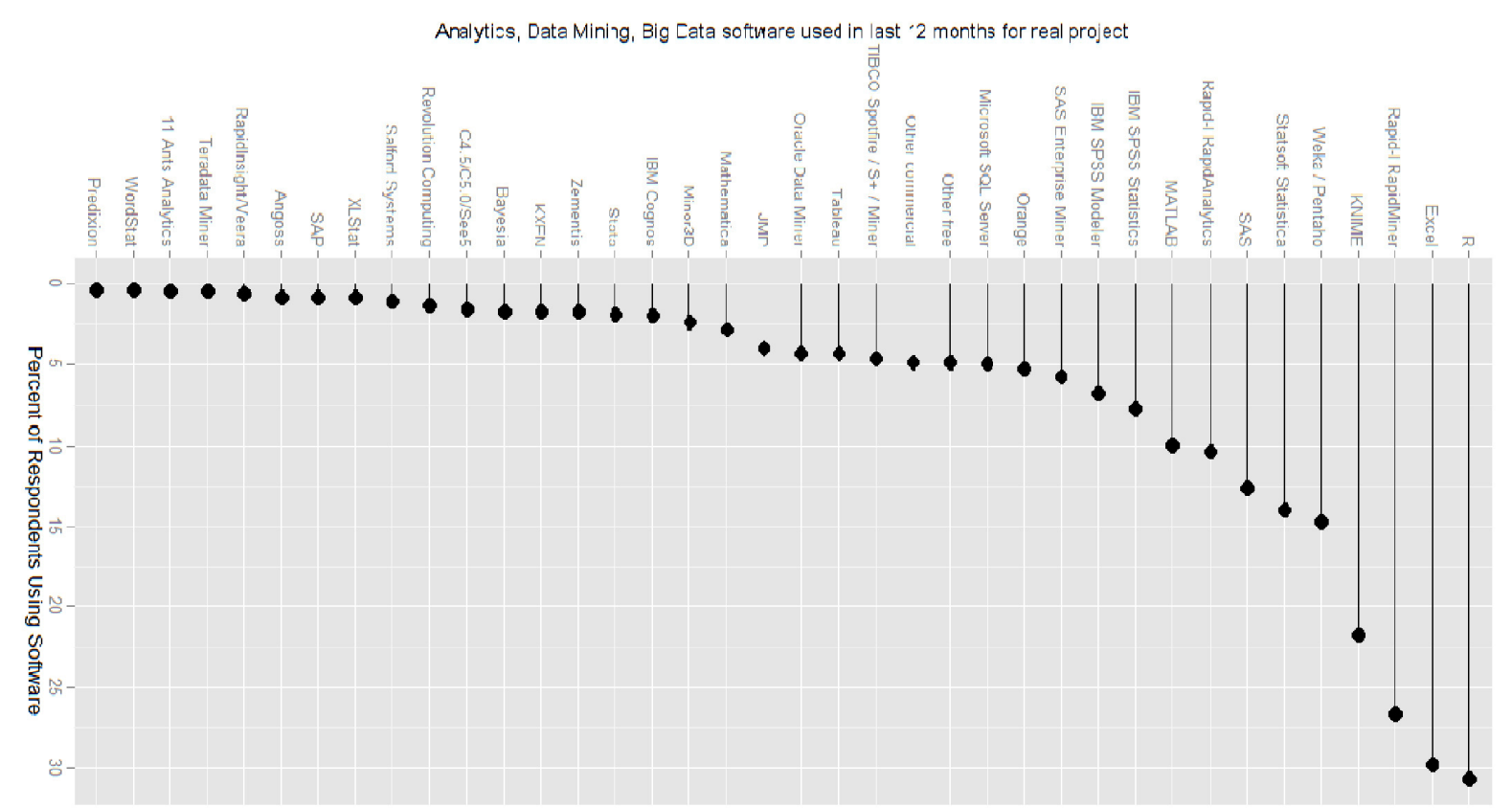

Figure 2. Analytics, Data Mining, Big Data software used in last two months of a project (KDNuggets, 2012)

The primary challenges that academicians/professors face when teaching Business Intelligence (BI) or Business Analytics (BA) stem from a shortage of teaching resources and support, indicating that professors who teach BI or BA lack the following: 1) Data sets; 2) Suitable cases; 3) Suitable textbooks; 4) BA/BI software; 5) Technical support/training. The pedagogy issues result from existing content not being shared adequately rather than resources not existing. That means instructors are forced to recreate content when teaching BI and BA.

The most popular software is EXCEL, mainly because it's easy to use and available to students at low/no cost. However, it suffers from having inadequate menu and not being able to perform certain statistical tests. Instead of EXCEL, instructors prefer SAS, SPSS or MINITAB, mainly because they can do many more statistical tests using these software programs given above. SAS and SPSS can handle large data sets, but the disadvantage of SAS and SPSS is that there is a longer learning curve compared to MINITAB or EXCEL. Another advantage of SAS and SPSS, they can handle problems with large data sets. Utilizing problems with large data sets is very desirable by firms in different industries and what the recruiters are looking for in hiring college graduates in their Business Analytics departments.

In terms of expenditures, even though SAS and SPSS appears lot more expensive on surface, schools can save money by using either SPSS or SAS, if faculty members utilize the resources offered to them by SPSS or SAS. Note that software is most desirable, because it is free when the faculty uses either SPSS or SAS, however EXCEL or MINITAB cannot handle problems with very large data sets, which should not be a problem in academic/university setting. When students get their first job in Business Analytics/Business Intelligence, they will be required to use a software program like SPSS or SAS. It will be better if SPSS or SAS is introduced to students earlier in their career, due to the fairly long learning curve for both software programs.

Previous studies have indicated a couple reasons that students decide on their majors. For example, an article on the Princeton Review website (2013) claims that there are two distinct reasons for students to choose a major. Students either decide on a major because it will prepare them for a specific field, or they choose it because they enjoy the subject. While career-focused majors direct students to a specific profession-like engineering, business, education, or nursing —, subject-focused majors — such as history — develop students' critical thinking skills and writing skills, which are also highly valued by employers (Princeton Review, 2013).

In this study, we use a multi-criteria decision making approach called the Analytic Hierarchy Process (AHP) to identify student reasons for choice of major. According to Safian, Ezwan and Hadi (2011), "The AHP is a structured technique for organizing and analyzing complex decisions. Based on mathematics and psychology, it was developed by Thomas L. Saaty in the 1970s and has been extensively studied and refined since then." Saaty (1994) claims that AHP is, "natural to our intuition and general thinking" which combines logic and intuition 
and that takes advantage of our ability to rank. (See Analytical Hierarchy Process by Strasser, Ozgur, \& Schroeder, 2002). Wang, Xie and Goh (1998) explain the use of AHP in the context of Quality Function Deployment. Strasser, Ozgur and Schroeder (2002) apply AHP in the context of selecting an undergraduate business major and make some interesting conclusions regarding the selection process. Giullian, Odom and Totaro (2002) reveal which majors are important. Hansen and Neuman (1999) demonstrate the predictive power of a student's major in determining how successful he/she will be in the work force. Kaynama and Smith (1996) use consumer behavior and decision models to aid students in choosing a major. Malgwi, Howe and Burnaby (2005) study the factors that affect student's choice of undergraduate/graduate college major. It further examines which majors are difficult enough to deter students from pursuing that area of study. St. John (1994) outlines how personal debt impacts the student's choice of an undergraduate major and which major(s) are affected the most and the least. The finance major is affected the most by personal debt while the management major is influenced the least by personal debt.

The questionnaire distributed to the students includes the following factors: Interest in Subject, Influence of Others, Job Availability and Growth Potential, Usage of Computer Skills, Usage of Interpersonal Skills and Usage of Mathematical Skills.

Alongside the results of student reasons for choice of major, we include in our study U.S. government data on expected salaries of graduates with the several majors, both upon graduation and ten years afterward. This data is displayed in Tables 1 and 2.

Table 1. Average salary of graduates for several majors with graduate degrees

Average Salaries for each of the majors with graduate degrees

\begin{tabular}{lll} 
Major & $\begin{array}{l}\text { Avg. Entry level position } \\
\text { salary }\end{array}$ & Avg. Salary for Experienced position \\
\hline Marketing & 60800 & 76000 \\
Finance & 64700 & 95013 \\
Management & 67380 & 101219 \\
Entrepreneurship & 70520 & 94628 \\
Operations Management & 70400 & \\
Business Analytics & 86490 & \\
International Business & 78220 & 125102 \\
MIS & 81190 & 114813 \\
Accounting & 62700 & 71666
\end{tabular}


Table 2. Percentage change in salaries between first time job and experienced worker for Graduates

\begin{tabular}{ll}
\hline $\begin{array}{l}\text { Percentage change for salaries between first time } \\
\text { job and experienced worker }\end{array}$ & \% Increase \\
Major & 25 \\
\hline Marketing & 46.9 \\
Finance & 50.2 \\
Management & 34.2 \\
Entrepreneurship & \\
Operations Management & \\
Business Analytics & 60 \\
International Business & 41.4 \\
MIS & 14.3 \\
Accounting & \\
\hline
\end{tabular}

Table 3. Average salary of undergraduates for several majors

Average Salaries for each of the majors

\begin{tabular}{lll} 
Major & $\begin{array}{l}\text { Avg. Entry level position } \\
\text { salary }\end{array}$ & Avg. Salary for Experienced position \\
\hline Marketing & 51900 & 76000 \\
Finance & 69000 & 90000 \\
Management & 46000 & 56000 \\
Entrepreneurship & 34500 & 54965 \\
Operations Management & 49000 & 60000 \\
Business Analytics & 85000 & 103000 \\
International Business & 78220 & \\
MIS & 58000 & 79000 \\
Accounting & 52000 & 63000
\end{tabular}


Table 4. Percentage change in salaries between first time job and experienced worker for Undergraduates

\begin{tabular}{ll}
\hline $\begin{array}{l}\text { Percentage change for salaries between first time } \\
\text { job and experienced worker }\end{array}$ \\
\hline Major & \% increase \\
\hline Marketing & 46.4 \\
Finance & 30.4 \\
Management & 21.7 \\
Entrepreneurship & 59.3 \\
Operations Management & 22.4 \\
Business Analytics & 21.2 \\
International Business & \\
MIS & 36.2 \\
Accounting & 21.2 \\
\hline
\end{tabular}

The data in Table 1 and Table 2 comes from Education Portal NACE Salary Survey Report (2013). We got results for graduates from Education Portal Salary Survey Report. However, we could not find operations management and business analytics majors average starting salaries. Then the authors calculated the percentage change in salaries between entry-level position and experienced position for each major. The results are produced by using the difference of salaries between entry level and experienced position divided by the salary for entry-level position.

Enrollment of international students in American universities has grown significantly in the past few years. Reliable sources place it at nearly eight percent of total enrollment. Most faculty members will be aware of the significant presence of international students in graduate programs for several years. What is more surprising is the very recent increase in international enrollment in some American undergraduate programs. At one mid-size American business school, international students increased from four percent to twenty-five percent of enrollees in just five years. Reasons for this growth in international enrollment include the facts that few Asian universities focus on career-oriented degrees and that brokers specializing in international enrollments act as recruiters overseas. Of particular interest is the fact that international students appear to have dramatically different preferences for majors as compared with "domestic" students. In one instance international students were three times as likely as their domestic counterparts to major in finance and comprised more than one half of total enrollment in that major. This suggests that valuable findings could occur if we can determine the reasons students chose their majors.

The growth of international students may be different for each institution and different programs of study and different countries; for example, finance majors draw more students than other business majors. In addition, Chinese, Arabic, and Indian students are more prevalent than other international students from other countries.

The overall trend in first-time enrollment of international graduate students for 2013 was predominately driven by students from India. The number of first-time enrollees from India increased $40 \%$ this year, substantially more than the 1\% increase in 2012 and $2 \%$ increase in 2011.

First-time enrollment among students from China increased 5\% in 2013, a substantially smaller increase than the $22 \%$ surge in 2012 and 21\% increase in 2011. This new finding marks the end of seven consecutive years of double-digit growth in first-time graduate enrollment of students from China. However, China continues to be the largest source of international graduate students, representing $34 \%$ of all international graduate students in the United States, according to survey respondents (Kent, 2013). (http://www.cgsnet.org/first-time-enrollment-international-graduate-students-10-percent) 
The following tables display statistics on majors within the field of business, marketing and management. The statistics included vary from number of students graduating from these majors, starting and mid-career salaries, number of jobs, and future job outlook for occupations stemming from the following majors. They highlight possible determinants for major selection by students in American higher education institutions. Analyzing this data can result in the further understanding of the breakdown of major selection.

Table 5. Number of students graduating and average salary information

Number of Students Graduating and Average Salary Information

\begin{tabular}{lccc}
\multicolumn{1}{c}{ Major } & $\begin{array}{c}\text { Yearly \# of students } \\
\text { graduating }\end{array}$ & Average Starting Salary & $\begin{array}{c}\text { Average Mid-career } \\
\text { Salary }\end{array}$ \\
\hline Marketing & 34,605 & $\$ 39,588$ & $\$ 75,319$ \\
Accounting & 60,526 & $\$ 44,520$ & $\$ 75,109$ \\
Finance & 35,945 & $\$ 44,855$ & $\$ 81,387$ \\
Entrepreneurship & 3,038 & $\$ 39,096$ & $\$ 85,275$ \\
\hline
\end{tabular}

(http://www.collegefactual.com)

Table 6. Average salaries in analytics-related jobs

\begin{tabular}{ll}
\hline Average Salaries in Analytics-related jobs & \\
\cline { 2 - 2 } Occupation & Average Salary \\
Predictive Analytics & $\$ 112,000$ \\
Marketing Analytics consultant & $\$ 80,000$ \\
VP Risk Management Analytic & $\$ 179,000$ \\
Senior Data Scientist & $\$ 112,000$ \\
Senior Healthcare Informatics Analyst & $\$ 90,000$ \\
Big Data Developer & $\$ 98,000$ \\
\hline
\end{tabular}

(http://www.indeed.com/salary/Predictive-Analytics.html)

Table 7. Salary, jobs and outlook of business, marketing and management related jobs

\begin{tabular}{lllll}
\hline \multicolumn{2}{l}{ Salary, jobs and outlook of business, marketing and management related jobs } & & \\
\hline Occupation & Median Pay & \# of jobs & Job outlook & $\begin{array}{l}\text { Employment } \\
\text { change }\end{array}$ \\
Market Research Analysts & $\$ 60,300$ & 415,700 & $32 \%$ & 131,500 \\
Accountants and Auditors & $\$ 63,550$ & $1,275,400$ & $13 \%$ & 166,700 \\
Financial Analysts & $\$ 76,950$ & 253,000 & $16 \%$ & 39,300 \\
Management Analysts & $\$ 78,600$ & 718,700 & $19 \%$ & 133,800 \\
Financial Managers & $\$ 109,740$ & 532,100 & $9 \%$ & 47,100 \\
\hline
\end{tabular}

(www.bls.gov) (Median pay and number of jobs is data drawn from the year 2012. Job outlook and employment change is over ten years into the future: 2012-22. Job outlook of $15 \%$ or more implies that the occupation is considered to be growing faster than average and all other outlooks in this table are considered as fast as average.)

The following graphs show the contributors of enrollment growth and highlight the importance of diversification in the internationalization strategies of American higher education institutions. It shows that the growth is concentrated in terms of source countries, types of institutions and level of education. The three charts from the 
article look into year-on-year growth from three different angles-- academic level, type of institution and source countries (Choudaha, 2013). (http://www.dreducation.com/2013/11/mobility-diversity-recruitment-trends.html)

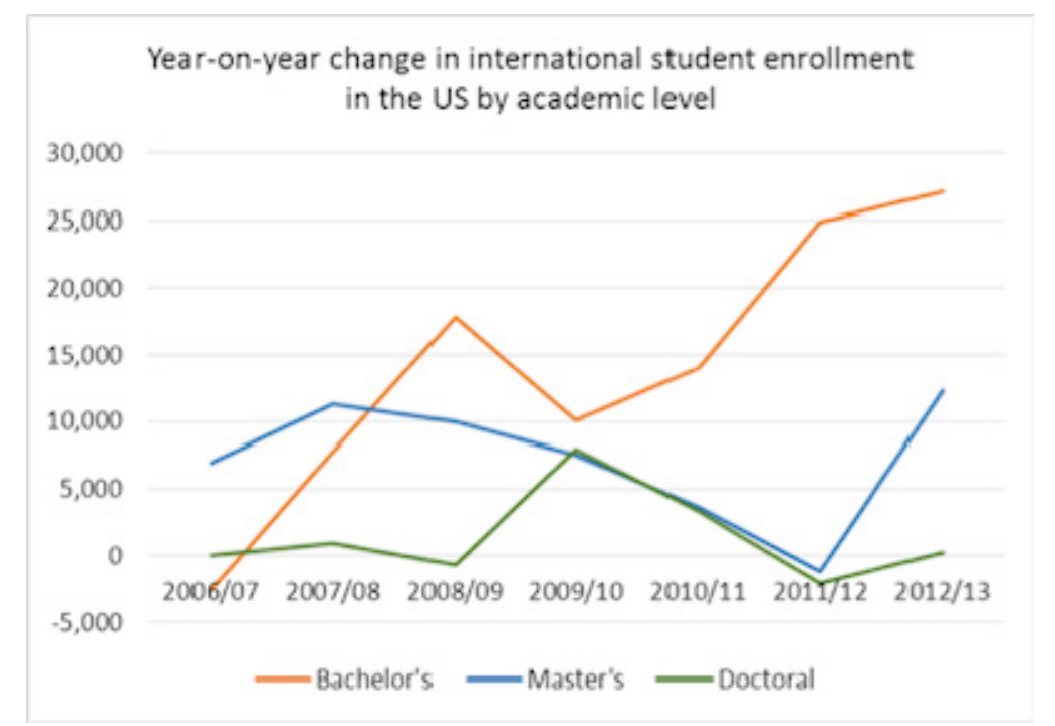

Figure 3. Higher revenue potential: Bachelor level enrollment becoming attractive

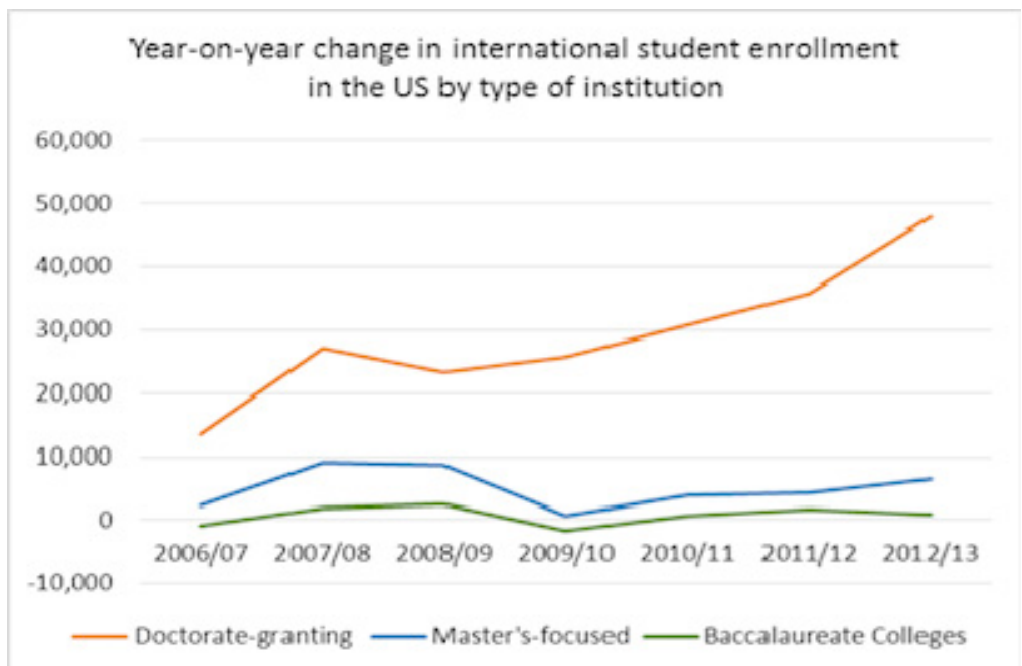

Figure 4. Big getting bigger: Doctorate-granting institutions driving growth 


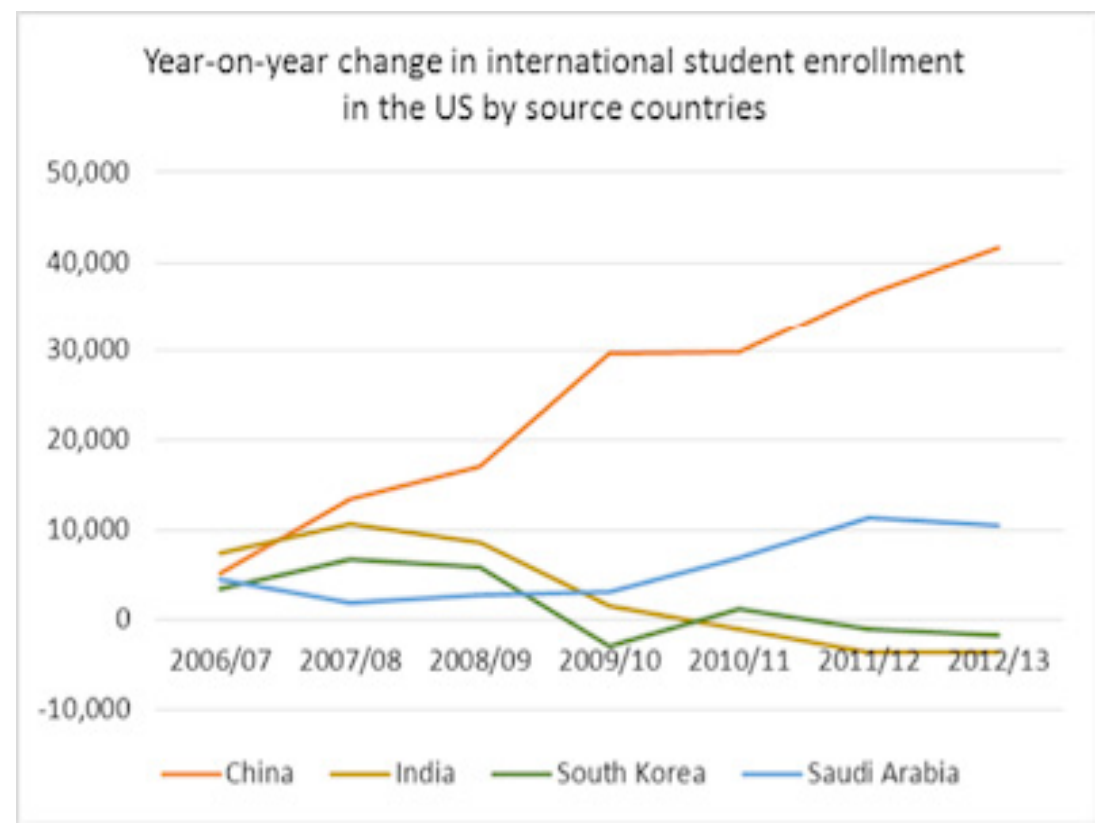

Figure 5. Demand from China and Saudi Arabia: Over-dependence on a few countries (Choudaha, 2013) http://www.dreducation.com/2013/11/mobility-diversity-recruitment-trends.html

Table 8. Enrollment of international students in the US universities 1948-2014

\begin{tabular}{|c|c|c|c|c|c|c|}
\hline \multicolumn{7}{|c|}{ INTERNATIONAL STUDENT AND U.S. HIGHER EDUCATION ENROLLMENT, 1948/49 - 2013/14 } \\
\hline Year & $\begin{array}{l}\text { Enrolled } \\
\text { Int'l Students }\end{array}$ & $\begin{array}{l}\text { Optional Practical } \\
\text { Training (OPT) }\end{array}$ & $\begin{array}{l}\text { Total Int'l } \\
\text { Students }\end{array}$ & $\begin{array}{l}\text { Annual } \\
\% \text { Change }\end{array}$ & $\begin{array}{l}\text { Total } \\
\text { Enrollment }{ }^{1}\end{array}$ & $\begin{array}{l}\% \\
\text { Int'l }\end{array}$ \\
\hline 1948/49 & - & - & 25,464 & - & $2,403,400$ & 1.1 \\
\hline 1949/50 & - & - & 26,433 & 3.8 & $2,445,000$ & 1.1 \\
\hline 1950/51 & - & - & 29,813 & 12.8 & $2,281,000$ & 1.3 \\
\hline $1951 / 52$ & - & - & 30,462 & 2.2 & $2,102,000$ & 1.4 \\
\hline $1952 / 53$ & - & - & 33,675 & 10.5 & $2,134,000$ & 1.6 \\
\hline $1953 / 54$ & - & - & 33,833 & 0.5 & $2,231,000$ & 1.5 \\
\hline $1954 / 55$ & - & - & 34,232 & 1.2 & $2,447,000$ & 1.4 \\
\hline $1955 / 56$ & - & - & 36,494 & 6.6 & $2,653,000$ & 1.4 \\
\hline $1956 / 57$ & - & - & 40,666 & 11.4 & $2,918,000$ & 1.4 \\
\hline
\end{tabular}




\begin{tabular}{|c|c|c|c|c|c|c|}
\hline $1957 / 58$ & - & - & 43,391 & 6.7 & $3,324,000$ & 1.3 \\
\hline $1958 / 59$ & - & - & 47,245 & 8.9 & no data & - \\
\hline $1959 / 60$ & - & - & 48,486 & 2.6 & $3,640,000$ & 1.3 \\
\hline 1960/61 & - & - & 53,107 & 9.5 & no data & - \\
\hline $1961 / 62$ & - & - & 58,086 & 9.4 & $4,146,000$ & 1.4 \\
\hline $1962 / 63$ & - & - & 64,705 & 11.4 & no data & - \\
\hline $1963 / 64$ & - & - & 74,814 & 15.6 & $4,780,000$ & 1.6 \\
\hline $1964 / 65$ & - & - & 82,045 & 9.7 & $5,280,000$ & 1.6 \\
\hline $1965 / 66$ & - & - & 82,709 & 0.8 & $5,921,000$ & 1.4 \\
\hline $1966 / 67$ & - & - & 100,262 & 21.2 & $6,390,000$ & 1.6 \\
\hline $1967 / 68$ & - & - & 110,315 & 10.0 & $6,912,000$ & 1.6 \\
\hline $1968 / 69$ & - & - & 121,362 & 10.0 & $7,513,000$ & 1.6 \\
\hline 1969/70 & - & - & 134,959 & 11.2 & $8,005,000$ & 1.7 \\
\hline 1970/71 & - & - & 144,708 & 7.2 & $8,581,000$ & 1.7 \\
\hline $1971 / 72$ & - & - & 140,126 & -3.2 & $8,949,000$ & 1.6 \\
\hline $1972 / 73$ & - & - & 146,097 & 4.3 & $9,215,000$ & 1.6 \\
\hline $1973 / 74$ & - & - & 151,066 & 3.4 & $9,602,000$ & 1.6 \\
\hline $1974 / 75^{(2)}$ & - & - & 154,580 & 2.3 & $10,224,000$ & 1.5 \\
\hline $1975 / 76$ & - & - & 179,344 & 16.0 & $11,185,000$ & 1.6 \\
\hline 1976/77 & - & - & 203,068 & 13.2 & $11,012,000$ & 1.8 \\
\hline $1977 / 78$ & - & - & 235,509 & 16.0 & $11,286,000$ & 2.1 \\
\hline 1978/79 & - & - & 263,938 & 12.1 & $11,260,000$ & 2.3 \\
\hline
\end{tabular}




\begin{tabular}{|c|c|c|c|c|c|c|}
\hline 1979/80 & 283,503 & 2,840 & 286,343 & 8.5 & $11,570,000$ & 2.5 \\
\hline 1980/81 & 308,432 & 3,450 & 311,882 & 8.9 & $12,097,000$ & 2.6 \\
\hline $1981 / 82$ & 323,419 & 2,880 & 326,299 & 4.6 & $12,372,000$ & 2.6 \\
\hline $1982 / 83$ & 333,365 & 3,620 & 336,985 & 3.3 & $12,426,000$ & 2.7 \\
\hline $1983 / 84$ & 335,494 & 3,400 & 338,894 & 0.6 & $12,465,000$ & 2.7 \\
\hline $1984 / 85$ & 337,803 & 4,310 & 342,113 & 0.9 & $12,242,000$ & 2.8 \\
\hline $1985 / 86$ & 339,627 & 4,150 & 343,777 & 0.5 & $12,247,000$ & 2.8 \\
\hline $1986 / 87$ & 344,879 & 4,730 & 349,609 & 1.7 & $12,504,000$ & 2.8 \\
\hline $1987 / 88$ & 351,387 & 4,800 & 356,187 & 1.9 & $12,767,000$ & 2.8 \\
\hline $1988 / 89$ & 359,334 & 7,020 & 366,354 & 2.9 & $13,055,000$ & 2.8 \\
\hline 1989/90 & 379,139 & 7,712 & 386,851 & 5.6 & $13,539,000$ & 2.9 \\
\hline 1990/91 & 398,759 & 8,770 & 407,529 & 5.3 & $13,819,000$ & 2.9 \\
\hline 1991/92 & 411,355 & 8,230 & 419,585 & 3.0 & $14,359,000$ & 2.9 \\
\hline 1992/93 & 427,608 & 11,010 & 438,618 & 4.5 & $14,487,000$ & 3.0 \\
\hline 1993/94 & 438,319 & 11,430 & 449,749 & 2.5 & $14,305,000$ & 3.1 \\
\hline 1994/95 & 439,427 & 13,208 & 452,635 & 0.6 & $14,279,000$ & 3.2 \\
\hline 1995/96 & 438,337 & 15,450 & 453,787 & 0.3 & $14,262,000$ & 3.2 \\
\hline 1996/97 & 439,859 & 18,125 & 457,984 & 0.9 & $14,368,000$ & 3.2 \\
\hline 1997/98 & 464,698 & 16,582 & 481,280 & 5.1 & $14,502,000$ & 3.3 \\
\hline 1998/99 & 474,091 & 16,842 & 490,933 & 2.0 & $14,507,000$ & 3.4 \\
\hline 1999/00 & 489,866 & 24,857 & 514,723 & 4.8 & $14,791,000$ & 3.5 \\
\hline 2000/01 & 526,809 & 21,058 & 547,867 & 6.4 & $15,312,000$ & 3.6 \\
\hline
\end{tabular}




\begin{tabular}{lllllll}
\hline $2001 / 02$ & 560,251 & 22,745 & 582,996 & 6.4 & $15,928,000$ & 3.7 \\
$2002 / 03$ & 558,530 & 27,793 & 586,323 & 0.6 & $16,612,000$ & 3.5 \\
$2003 / 04$ & 543,169 & 29,340 & 572,509 & -2.4 & $16,911,000$ & 3.4 \\
$2004 / 05$ & 532,040 & 32,999 & 565,039 & -1.3 & $17,272,000$ & 3.3 \\
$2005 / 06$ & 526,670 & 38,096 & 564,766 & -0.05 & $17,487,000$ & 3.2 \\
$2006 / 07$ & 541,324 & 41,660 & 582,984 & 3.2 & $17,759,000$ & 3.3 \\
$2007 / 08$ & 567,039 & 56,766 & 623,805 & 7.0 & $18,248,000$ & 3.4 \\
$2008 / 09$ & 605,015 & 66,601 & 671,616 & 7.7 & $19,103,000$ & 3.5 \\
$2009 / 10$ & 623,119 & 67,804 & 690,923 & 2.9 & $20,428,000$ & 3.4 \\
$2010 / 11$ & 647,246 & 76,031 & 723,277 & 4.7 & $20,550,000$ & 3.5 \\
$2011 / 12$ & 679,338 & 85,157 & 764,495 & 5.7 & $20,625,000$ & 3.7 \\
$2012 / 13$ & 724,725 & 94,919 & 819,644 & 7.2 & $21,253,000$ & 3.9 \\
\hline & & & & & & \\
$2013 / 14$ & 780,055 & 105,997 & 8.1 & $21,216,000$ & 4.2 \\
\hline
\end{tabular}

Institute of International Education. (2014). "International Student Enrollment Trends, 1948/49-2013/14". Open Doors Report on International Educational Exchange. Retrieved from http://www.iie.org/opendoors

Looking at Table 8, we can see the growth in International students in the Total International Students column. In addition, we can also see the growth in international students in the International Students Percentage column. The percentage started as 1.1 in 1948, and changed to 4.2 in 2014. 
Table 9. Leading countries of origin for international students at U.S. universities

\begin{tabular}{|c|c|c|c|c|}
\hline Rank and Country of Origin & $2012-13$ & $2013-14$ & Percent & Percent \\
\hline World Total & 819,644 & 886,052 & 100 & +8.1 \\
\hline 1. China & 235,597 & 274,439 & 31 & +16.5 \\
\hline 2. India & 96,754 & 102,673 & 11.6 & +6.1 \\
\hline 3. South Korea & 70,627 & 68,047 & 7.7 & -3.7 \\
\hline 4. Saudi Arabia & 44,566 & 53,919 & 6.1 & +21 \\
\hline 5. Canada & 27,357 & 28,304 & 3.2 & +3.5 \\
\hline 6. Taiwan & 21,867 & 21,266 & 2.4 & -2.7 \\
\hline 7. Japan & 19,568 & 19,334 & 2.2 & -1.2 \\
\hline 8. Vietnam & 16,098 & 16,579 & 1.9 & +3 \\
\hline 9. Mexico & 14,199 & 14,779 & 1.7 & +4.1 \\
\hline 10. Brazil & 10,868 & 13,286 & 1.5 & +22.2 \\
\hline 11. Turkey & 11,278 & 10,821 & 1.2 & -4.1 \\
\hline 12. Iran & 8,744 & 10,194 & 1.2 & +16.6 \\
\hline 13. United Kingdom & 9,467 & 10,191 & 1.2 & +7.6 \\
\hline 14. Germany & 9,819 & 10,160 & 1.1 & +3.5 \\
\hline 15. France & 8,297 & 8,302 & 0.9 & +0.1 \\
\hline 16. Nepal & 8,920 & 8,155 & 0.9 & -8.6 \\
\hline 17. Hong Kong & 8,026 & 8,104 & 0.9 & +1 \\
\hline 18. Nigeria & 7,316 & 7,921 & 0.9 & +8.3 \\
\hline 19. Indonesia & 7,670 & 7,920 & 0.9 & +3.3 \\
\hline 20. Thailand & 7,314 & 7,341 & 0.8 & +0.4 \\
\hline 21. Kuwait & 5,115 & 7,288 & 0.8 & +42.5 \\
\hline 22. Colombia & 6,543 & 7,083 & 0.8 & +8.3 \\
\hline 23. Venezuela & 6,158 & 7,022 & 0.8 & +14 \\
\hline 24. Malaysia & 6,791 & 6,822 & 0.8 & +0.5 \\
\hline 25. Spain & 5,033 & 5,350 & 0.6 & +6.3 \\
\hline
\end{tabular}

Redden, E. (2014). "Open Doors" report finds increases in international enrollment, study abroad|InsideHigherEd.com. Retrieved April 8 , 2015 , from 
https://www.insidehighered.com/news/2014/11/17/open-doors-report-finds-increases-international-enrollment-st udy-abroad

As we can see, in Table 9, Chinese students in US universities have the highest percentage and highest enrollment, followed by Indian, South Korean, and Saudi Arabian students.

The Council of Graduate Schools (CGS) today reported a $10 \%$ increase in the first-time enrollment of international graduate students from 2012 to 2013, a growth that adds to $8 \%$ increases in this figure in each of the last two years. Total enrollment of international graduate students among responding institutions reached 220,000 in 2013. The findings were part of the 2013 CGS International Graduate Admissions Survey, Phase III: Final Offers of Admission and Enrollment (Choudaha, 2013). (http://www.cgsnet.org/first-time-enrollment-international-graduate-students-10-percent)

The recent release of the Institute of International Education's 2012 Open Doors data showed another rise in international student enrolments in the United States, reaching 764,495. This figure marks an increase of 5.7\% from $2011(723,277)$ and nearly a third since $2007(582,984)$.

Despite this growth, international students still only account for a small share of students on US campuses-about $3.5 \%$ of a total of 20.5 million students enrolled in 2011. Certainly US colleges and universities have plenty of room to grow international enrolments to further internationalize their institutions.

For one, much of the recent enrolment growth has been driven by just three countries, China, India, and Saudi Arabia. Since 2007, enrolments from China have grown by $186.5 \%$ while enrolments from Saudi Arabia have grown by a staggering $332.9 \%$. The first time enrollment of India students showed a growth rate of $40 \%$. Indeed, international student enrolments in the US have declined since 2009 if China, India, and Saudi Arabia are excluded (Guhr, 2012; Kent, 2013).

http://www.universityworldnews.com/article.php?story=20121123064223433

http://www.cgsnet.org/first-time-enrollment-international-graduate-students-10-percent

\section{Discussion and Future Research}

The research reported in this paper seeks to provide business school faculty and administrators with some perspective on student choices of major, number of jobs, and starting and mid-career salary. The number of students graduating is most for accounting major at 60,526 and least for entrepreneurship major at 3038 . The starting salaries is highest for finance majors at $\$ 44855$ and lowest for entrepreneurship major at $\$ 39096$. The mid-career salaries is the highest for entrepreneurship major at $\$ 85,275$ and the lowest for accounting major at $\$ 75,105$, and the next lowest mid-career salary is for marketing major at $\$ 75,319$. In addition, it shows the growth of international students in US universities both at graduate and undergraduate levels, especially the largest growth among Chinese, Arabic, and Indian students.

\section{References}

National Occupational Employment and Wage Estimates. (2011). Bureau of Labor Statistics.

Analytics-related salary information. (2015). Retrieved April 9, 2015, from http://www.indeed.com/salary/Predictive-Analytics.html

Business analytics. (2013). Retrieved October 23, 2013, from http://en.m.wikipedia.org/wiki/Business_analytics

Bureau of Labor Statistics. (2015). Retrieved April 13, 2015, from http://www.bls.gov/

Choudaha, R. (2013). Three international student enrollment growth trends in the us higher education institutions. http://www.dreducation.com/2013/11/mobility-diversity-recruitment-trends.html

College Major Statistics. (2013). Retrieved April 9, 2015, from http://www.collegefactual.com/

Giullian, M. A., Odom, M. D., \& Totaro, M. W. (2002). Developing essential skills for success in the business world: A look at forecasting. Journal of Applied Business Research, 16 (3), 135-149.

Guhr, D. (2012). US international student growth rates unsustainable. http://www.universityworldnews.com/article.php?story=20121123064223433

Hansen, J. C., \& Neuman, J. L. (1999). Evidence of concurrent prediction of the campbell interest and skill survey (CISS) for college major selection. Journal of Career Assessment, 7(3), 239-247. http://dx.doi.org/10.1177/106907279900700304 
Institute of International Education. (2014). International Student Enrollment Trends, 1948/49-2013/14. Open Doors Report on International Educational Exchange. Retrieved from http://www.iie.org/opendoors

Kaynama, S. A., \& Smith, L. W. (1996). Using consumer behavior and decision models to aid students in choosing a major. Journal of Marketing for Higher Education, 7(2) 57-73. http://dx.doi.org/10.1300/J050v07n02_05

KDNuggets. (2012). What analytics, data mining, big data software you used in the past 12 months for a real project. Retrieved from http://www.kdnuggets.com/polls/2012/analytics-data-mining -big-data-software.html\#bigdata

Kent, J. (2013). First-time Enrollment of International Graduate Students Up 10 Percent. http://www.cgsnet.org/first-time-enrollment-international-graduate-students-10-percent

Malgwi, C. A., Howe, M. A., \& Burnaby P. A. (2005). Influence on students' choice of college major. Journal of Education for Business, 80(5), 275-282. http://dx.doi.org/10.3200/JOEB.80.5.275-282

The Princeton Review. (2013). Choosing a major. Retrieved from http://www.princetonreview.com/college/choosing-a-major.asp

Redden, E. (2014). "Open Doors" report finds increases in international enrollment, study abroad|InsideHigherEd.com. $\quad$ Retrieved April $\quad 8, \quad 2015, \quad$ from https://www.insidehighered.com/news/2014/11/17/open-doors-report-finds-increases-international-enrollme nt-study-abroad

Saaty, T. L. (1994). How to make a decision: The Analytic Hierarchy Process. Interfaces, 24(6), 19-43. http://dx.doi.org/10.1287/inte.24.6.19

Safian, M., Ezwan, E., \& Hadi, A. (2011). The evolution of Analytical Hierarchy Process (AHP) as a decision making tool in property sectors. International Proceedings of Economic Development \& Research, 6(28).

St. John, E. P. (1994). The influence of debt on choice of major. Journal of Student Financial Aid, 24(1), 5-12.

Strasser, S. E., Ozgur, C., \& Schroeder, D. L. (2002). Selecting a business college major: An analysis of criteria and choice using the analytical hierarchy process. American Journal of Business, 17(2), 47-56. http://dx.doi.org/10.1108/19355181200200010

Wang, H., Xie, M., \& Goh, T. N. (1998). A comparative study of the prioritization. Matrix Method and the Analytic Hierarchy Process Technique in Quality Function Deployment. Total Quality Management, 9(6) 421-430. http://dx.doi.org/10.1080/0954412988361

Wixom, B., Ariyachandra, T., Goul, M., Gray, P., Kulkarni, U., \& Phillips-Wren, G. (2011). The current state of business intelligence in academia. Communications of the Association for Information Systems, 29(16), 299-312.

\section{Appendix 1. Schema of job titles and areas of interest for the respective majors.}

\section{Marketing}

a) Sales

b) Marketing Research

c) Advertising

\section{Finance}

a) Financial Sales

b) Stock Market sales (stocks and or bonds)

c) Trading futures or derivatives

d) Serving as financial officer of a firm or a corporation

e) Salesperson of financial services

\section{Management}

a) Manager of a service organization

b) Manager of a manufacturing organization 
c) Manager of an entry level position

d) Manager of an mid-level or higher management position

e) Strategic Management position

f) Tactical Management position

\section{Entrepreneurship}

a) Owning your own company

b) Preparing a business plan

c) Searching for sources of funds

d) Filing for reorganization or bankruptcy

e) How to plan for different businesses

\section{Operations Management}

a) Inventory Management \& Scheduling and to work towards earning the CPIM (Certified in Production and Inventory Management) designation

b) Quality Management and work towards earning CQE (Certified Quality Engineer) designation

c) Supply Chain Management work toward earning the CSCP (Certified Supply Chain Professional) designation

d) Production controller

e) Master Production Scheduler

f) Planner/scheduler

\section{Business Analytics}

a) How to analyze large data

b) How to analyze small data

c) Foundations of Statistical analysis

d) How to use software to analyze data either using statistical software packages like Excel, SPSS or SAS and management science software packages like GAMS

e) How to use computer programming to analyze business data

\section{International Business}

a) How to use vertical integration in the context of International Business

b) How to use Strategic Management for an International Business

c) Utilizing foreign language skills

d) Consideration of Cultural barriers

e) Consideration of language barriers

f) How to use local business talent

g) How to utilize international business expertise

\section{Management Information System}

a) Knowledge of Systems like SAP or ORACLE and integration of such systems into business

b) Utilization of ERP in the context of business and breaking down unnecessary business silos

c) Development of artificial intelligence and manufacturing resource planning systems to help the company to develop a better business plan

d) Development of Decision Support Systems to help the company to organize for better planning

e) To help students earn certifications in SAP or ORACLE.

\section{Accounting}

a) Teaching/learning X's and O's of accounting and to prepare the students to obtain their CPA's (Certified Public Accounting) 
b) Teaching/Learning the principles of Managerial Accounting and prepare the students to obtain their CM A'S (Certified Managerial Accounting)

c) Teaching/learning the principles of not-for-profit accounting

d) Teaching/learning the principles of taxation for both individual taxes and corporate taxes

e) Teaching/Learning GAAP (Generally Accepted Accounting Principles).

f) Prepare students for Internal Auditing exam

\section{Copyrights}

Copyright for this article is retained by the author(s), with first publication rights granted to the journal.

This is an open-access article distributed under the terms and conditions of the Creative Commons Attribution license (http://creativecommons.org/licenses/by/3.0/). 